\title{
GIS Based Analysis of Niger-Benue River Flood Risk and Vulnerability of Communities in Kogi State, Nigeria
}

\author{
Chukwunonso Emmanuel Ozim, Oladeinde Stephen Olufemi, Abraham Salamatu Ekpo, \\ Nnaemeka Kosiso Alamaeze, and Michael Udochukwu Mbanaso
}

\section{ABSTRACT}

Flood remains one of the most common natural disasters. Its rate of occurrence and the associated destructive tendency are on a rising scale across the globe. Flood risk may increase due to human activities. It could also decrease by appropriate flood management and planning. However, this requires upgraded and newly generated reliable and up to date floodplain and flood vulnerability maps. Hence, this study analysed the Niger-Benue river flood risk and vulnerability of $\mathbf{2 5 6}$ communities in Kogi State. The aim is to generate reliable up to date flood vulnerability maps that categorises the communities into different vulnerability zones and identify likely locations for erecting flood shelter/refugee camps during flood events in the State. Shuttle Radar Topography Mission (STRM) Digital Elevation Datasets, the spatial location of 256 communities, shapefiles of Kogi State's administrative boundaries and Niger-Benue river basin were among the datasets acquired for the study. The Digital Elevation Model (DEM) of the study area was created to depict topography and the heights of each component of the terrain. Also, a $3 \mathrm{~km}$ buffer distance was created around the Niger-Benue river and four vulnerability zones were defined based on the terrain and proximity components of each community. Furthermore, choropleth maps were generated for each vulnerability zone based on the number of communities per Local Government Area (LGA). Findings of this study revealed that out of the 256 sampled communities, 161 representing $62.89 \%$ are exposed to varying degrees of vulnerability due to Niger-Benue flooding. Out of these, 33 $(\mathbf{1 2 . 8 9 \%})$ are highly vulnerable, whereas each of the vulnerable (64) and marginally vulnerable (64) communities accounted for $25 \%$. The rest $37.11 \%$ constituted the not vulnerable communities (95). Out of the highly vulnerable communities, $27.27 \%$ accounted for those located on river banks and $72.73 \%$ for those located within a $3 \mathrm{~km}$ distance from the river. The majority of the riverbank communities were found in Kogi, Lokoja and Ajaokuta LGAs. Igalamela Odolu, Kogi, Ofu and Bassa were among the LGAs with a high number of vulnerable communities. The not vulnerable communities were mostly located around the Agbaja Plateau and Okoro-Agbo hills in Ijumu, Kabba/Bunu and Yaba East LGAs. It was concluded that the 9 communities (Ajaokuta, Eroko, Iche, Jamata, Numai, Okume, Agodo, Denbor and Gunji Twaki) located on river banks are exposed to the highest level of flood risk and invariably, the devastating impact of flood in Kogi State. Most communities in Ijumu, Kabba/Bunu and Yaba West LGAs are less likely to be affected by Niger-Benue River flooding. It is therefore recommended that communities within the highly vulnerable zones, beginning with the 9 located on river banks should be relocated to higher terrains. Also, future settlement development should be discouraged in the zone by the collaborative efforts of the State and LGA authorities. Further studies should be conducted around Ijumu LGA in view of identifying the most suitable locations for possible flood shelter/refugee camp development in the study area.

Keywords: Analysis, Community, Flood, GIS, Risk, Vulnerability.
Published Online: October 08, 2021

ISSN: $2684-446 \mathrm{X}$

DOI : 10.24018 /ejgeo.2021.2.5.187

\section{E. Ozim*}

GIS Unit, Enugu Electricity Distribution Company, Enugu State, Nigeria.

(e-mail: nuelsokky@gmail.com)

O. S. Olufemi

National Space Research and Development Agency, Obasanjo Space Centre, FCT, Nigeria.

(e-mail: femioladeinde@gmail.com)

A. S. Ekpo

Department of Environmental Management, Faculty of Environmental Science, Nasarawa State University, Keffi, Nigeria.

(e-mail: abrahamsalamatu ${ }^{\circledR}$ gmail.com) N. K. Alamaeze

GIS Unit, Enugu Electricity Distribution Company, Enugu State, Nigeria.

(e-mail: alamaezennaemeka ${ }^{@}$ gmail.com) M. U. Mbanaso

Department of Urban and Regional Planning, Faculty of Environmental Science, Nasarawa State University, Keffi, Nigeria

(e-mail: mbanasomu@gmail.com)

*Corresponding Author

\section{INTRODUCTION}

Flood remains one of the most common natural disasters; its rate of occurrence and the associated destructive tendency are on the rising scale across the globe. It is connected with immense loss of lives, displacement of settlements and destruction of properties and farmlands degradation. Although several policies and engineering measures have been developed to help minimize the adverse effects of flood, flooding still remains one of the greatest threats to the 
property and safety of human communities in the world among all-natural hazards [1]. Consequently, Schramn and Dries [2] argued that flooding is the topmost natural disaster which rather than declining, is becoming a greater threat. Every time and anywhere flooding occurs, lots of damages are incurred and these damages range from considerable loss of lives, economic loses, destruction of built and natural environment, disruption of local institution to livelihood, and disempowering of the local community thereby hindering nations from achieving sustainable development [3]. These damages are associated with environmental, economic, social, and demographic and psychological dimensions.

"Flooding is a general temporary condition of partial or complete inundation of normally dry areas from overflow of inland or tidal waters or from unusual and rapid accumulation or runoff" [4]. According to the European Commission [5], flood can be defined as "a natural phenomenon that results in the temporary submerging with water of a land that does not occur under normal conditions". Despite its destructive disposition, flooding cannot be prevented as it is a naturally occurring event [6], [7].

Additionally, flood can also be induced by anthropogenic activities that interferes with natural processes such as increase in settlement areas, population growth and economic assets over low lying plains which causes alterations in the natural drainage and river basin patterns, deforestation and climate change and ultimately give rise to flood prone conditions [5], [8], [9]. Floods cause about one third of all deaths, one third of all injuries and one third of all damage from natural disasters [10]. During a World Conference on Natural Disaster Reduction organized by the United Nations in Yokohama in May 1994, one of the 10 "principles" of the Yokohama Strategy is that "risk assessment is a required step for the adoption of adequate and successful disaster reduction policies and measures". The terms "floods", "flood hazard", and "flood risk" cover a broad range of phenomena. The terms such as "flood risk" and "flood losses" are essentially our interpretation of the negative economic losses and social consequences of natural events. Flood risk may increase due to human activity and may as well decrease by appropriate flood management and planning [11].

Ezigbo [12] and Centre for Human Security of the Olusegun Obasanjo Presidential Library Foundation [13] reported that Nigeria suffered property and business loses valued at N2.6 trillion from most recent and wide-reaching 2012 flooding that ravaged more than $2 / 3$ of the states in the country. They suggested that the losses were aggravated by the increased development of residential, commercial and tourist activities building, particularly along the river front/coastal margins which invariably increases the population of people living in such area. These rise in population within coastal areas coupled with increment of impervious surfaces, alteration of hydrological systems (i.e watershed), and diminished capacity of these systems to hold and store surface run-off naturally result to increment of communities' vulnerability to flood risk.

In the same vein, Adedeji et al. [14] described flooding as a natural hazard, which can be exacerbated by human interference on the urban modification and alteration in the urban space or area, whereas the disastrous consequences are attributable to the degree settlement development and human activities in vulnerable areas. Therefore, there is need for regular flood risk and vulnerability assessment of communities along flood plain areas for proper and effective environmental planning towards achieving goal number 11 of the Sustainable Development Goals (SDGs) which seeks to make cities and human settlements safe, resilient, and sustainable.

Flooding is a common event in Nigeria during raining seasons of every year. Specifically, in Kogi State where quite a substantial number of its settlements are located in relatively low-lying areas of the Niger-River Basin and flood plains, flooding occurs almost every raining season. In 2012 for instance, the state was categorized among the worst hit states (Kogi, Adamawa, Anambra, Oyo, Bayelsa, Delta, Benue, and Plateau) at the wake of the national flood disaster that submerged several communities in Nigeria [15]. According to Aderoju et al. [16], at the peak of the disaster, 345,273 people were internally displaced, numerous building and industries were fully or partially submerged for more than four (5) months.

Although the National Emergency Management Agency (NEMA) predicted the impendence of the flood disaster and advised that activities and residence should be relocated from the floodplain to the upland areas, spatial and synthesized information was not made available. Such information involves the detection of the areal extent along the Niger and Benue rivers that is at risk or vulnerable to flooding. Planners and policy makers do not possess required platform for producing such information. This is evidenced by the report that several refugee camps which were setup in the presumed safe ground were equally overwhelmed by the flood [17]. Ensuring that all vulnerable areas are identified and delineated for precautionary measures remain the substantive and sustainable approach to mitigating the effects of river flooding [18]. In addition, systematic (spatial) information will also be resourceful in post impact assessment and rapid assessment of the extent of damage. To deal with this, it is pertinent to adopt a powerful framework with geovisualization capability to analyse, model and visualise output for effective decision making.

According to Ikusemoran [15], The Presidential Technical Committee for Assessment of the Impact of the 2012 flood disaster in Nigeria, observed that, scarcity of floodplain and vulnerability maps, and great number of settlements on floodplains were among the factors that aggravated the losses and damages accrued to the disaster. Based on their observations, advocated for short, medium and long-term prevention/mitigation plans against future occurrences. Among the recommendations were: relocation of communities living within river banks and floodplain, upgrading and generation of reliable up to date floodplain and flood vulnerability maps for the country.

In accordance with the recommendations, the Federal Government through the National Emergency Management Agency is making a long-term plan of resettling (where possible) the affected communities in all the states to safer locations as well as short term plan of ensuring that effective early warning systems are put in place [15]. Hence, it is imperative that the degree of vulnerability of LGAs and communities in Kogi State are investigated and delineated for effective implementation of such long- and short-term plans. 
Jeb and Aggarwal [4] stated that minimizing flood risk largely a function of the volume of available and accessible information on floods and knowledge of the areas that are likely to be affected during flood events. Therefore, it is necessary to use modern day techniques in developing measures that will help government and relief agencies with the identification of flood prone areas and planning against future flood occurrences. A combination of remote sensing and geographical information system (GIS) present capable tool for investigating and mapping areas/communities that are less or more vulnerable to flooding.

The use of remotely sensed data in GIS environment has proven to be the most resourceful approach for river flood assessment and risk analysis [18]. Geographic information system (GIS) has the capability of automated data generation and decision-making ability on spatially referenced and nonspatial features. Thus, this study employs GIS techniques to analyse Niger-Benue river flood risk and vulnerability of 256 communities in Kogi State.

\section{MATERIALS AND METHODS}

Kogi state is found in the central region of Nigeria, it is popularly called the confluence state because of the coming together of River Niger and River Benue at its capital city, Lokoja. The State which is located between latitude $6^{\circ} 30^{\prime} \mathrm{N}$ and $8^{\circ} 45^{\prime} \mathrm{N}$ of the Equator and longitude $5^{\circ} 20^{\prime} \mathrm{E}$ and $7^{\circ} 53^{\prime} \mathrm{E}$ of the Meridian occupies a total land area of $29,165 \mathrm{~km}^{2}$ [16]. Kogi State which has 21 LGAs was formed in 1991 from parts of Kwara state and Benue State. It is bordered by Federal Capital Territory (FCT) to the North, Nassarawa state to the Northeast, Benue State to the South, Enugu State to the Southeast, Anambra State to the south, Edo State to the Southwest, Ondo and Ekiti to the West, Niger State to the North and Kwara to the Northwest.

The climate of Kogi State is characterized by wet and dry Aw type of climate as classified by Koppen. It has annual rainfall of $1016 \mathrm{~mm}$ and $1524 \mathrm{~mm}$, ninety percent of which falls between April and October with mean annual temperature of $27.7^{\circ} \mathrm{C}$ [19]. The dry harmattan winds are felt mostly between December and February owing to the influence of North East Trade Wind $(\mathrm{Ct})$ whereas the Tropical Maritime Air (Mt) brings rainfall over the city during the rainy season. The dry season is between November and March but may be punctuated by sporadic showers during this season. Nevertheless, the area is subjected to cool dry North Easterly (NE) wind originating from the Sahara Desert [20]. Fig. 1 presents map of Kogi State showing the drainage network.

Kogi State is drained by the Niger and Benue Rivers and their tributaries. The confluence of the Niger and Benue Rivers which could be viewed from the top of Mount Patti is located within the state. The Benue River is navigable as far as Garua in the rainy season floods, but up to Makurdi in Benue State in the dry season [16]. The Mabolo (Anambra) is the biggest river in Igalaland. Mabolo, Okura, Ubele and Ofu rivers run off the Dekina-Ankpa-Oturkpo watershed. Osomera Falls at Kilometre Four on Okene-Ajaokuta Road, Ofejiji Falls in Okura-Olafia and Egeneja Warm Spring in Bassa Local Government Area are other drainage features. The bigger rivers have wide flood plains such as the portion of the lower Niger in Kogi state, which is more than 1,600 metres wide at Lokoja [21], whereas the small streams have narrow valleys.

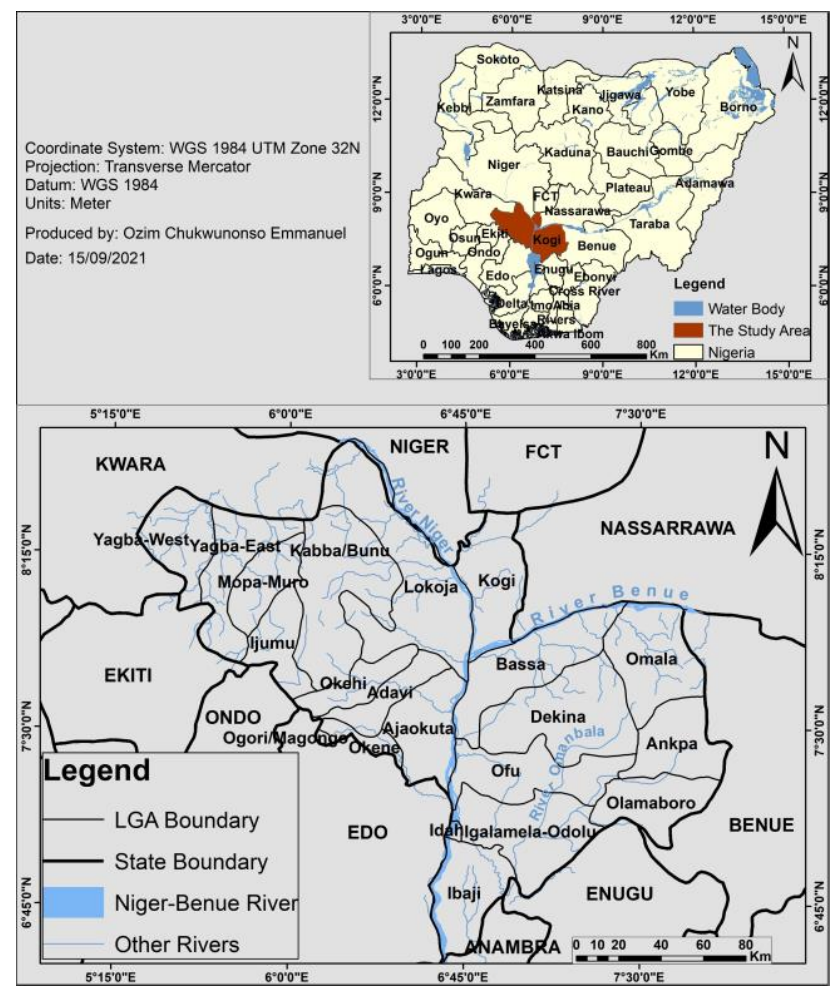

Fig. 1. Kogi State Showing Drainage Network

The land areas in Kogi State rises from about 300 metres along the Niger-Benue conflate, to the heights of between 300 and 600 metres above sea level in the uplands. Agbaja Plateau, which ranges from 335 to 366 metres above sea level, and the much higher Okoro-Agbo hills at Ogidi in ljumu LGA are some of the predominant landforms of the state. The general terrain is undulating and characterised by high hills, plateaus and numerous inselbergs and elongated ridges [16]. Fig. 2 shows the terrain of the study area.

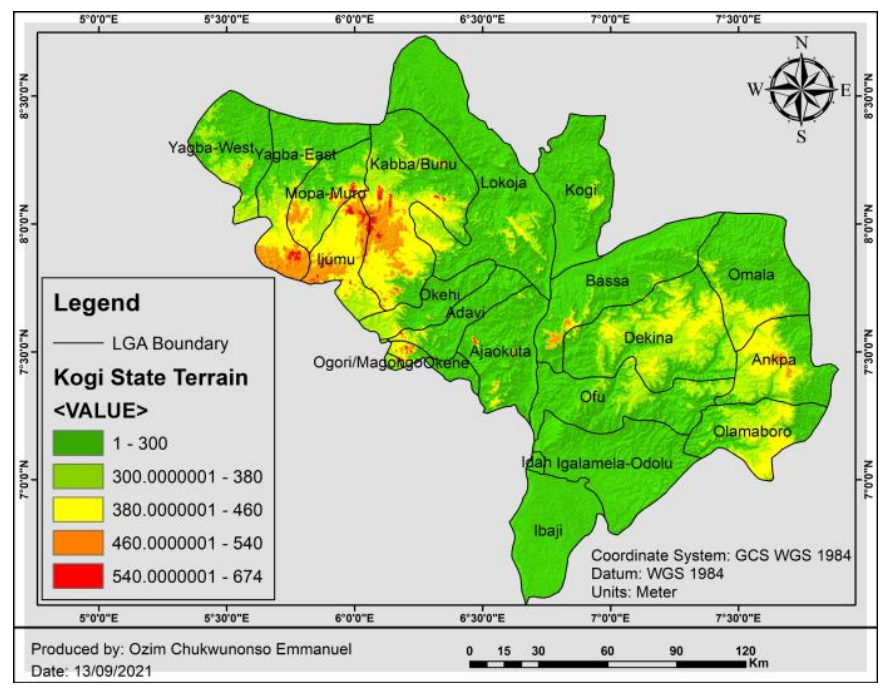

Fig. 2. Terrain of Kogi State.

\section{A. Data Collection}

The datasets collected for this study include Digital Elevation Datasets acquired from Shuttle Radar Topography Mission (STRM); spatial locations of 256 communities 
obtained through fieldwork using GPS, and from Diva-GIS spatial data download; shapefile of Kogi State's administrative boundaries and the basin of river Niger and River Benue digitized from Atlas Map. We processed the datasets using ArcGIS software (version 10.2.2) and Microsoft Excel (Office 2016).

\section{B. Data Processing and Analysis}

The scanned Atlas Map was imported into the ArcGIS environment and georeferenced using spatially distributed $\mathrm{X}$ and $\mathrm{Y}$ coordinate tie-points. Various features of interest like rivers, river basins and LGAs were carefully digitized and converted into a Projected Coordinate System (World Geodetic System [WGS] 1984, Universal Transverse Mercator, Minna Datum, Nigeria, and zone 32). The choice of a projected Coordinate System over a Geographic Coordinates System is because the latter has base reference units (decimal degrees) which are not linear units of measure. Hence, do not support areas, distances and heights calculations which are of paramount importance in this study. The names and corresponding XY coordinates (latitudes and longitudes) of the 256 communities were entered into Microsoft Excel and added to the ArcGIS environment as point data using the "Add XY data" module.

\section{Creation of Digital Elevation Model (DEM) of Kogi State}

We created a single image from the eight scenes of Digital Elevation Datasets using the 'mosaic to new' raster process. Furthermore, we used the shapefile of Kogi State to clip the portion of the mosaicked image that masks the State. "Since risk zone assessment of river floods largely depends on proximity to a waterbody and the terrain of the area" [5], [22], [23], it becomes imperative to model the elevation characteristics of the study area using the clipped elevation image. Modelling the digital elevation of the study area reveals the topography and the heights of respective components of the terrain, and the proximity to the waterbody as shown in fig. 2. Based on the height components of the State as revealed by the DEM, we categorized the State into two: the low-lying plains comprised of areas that are equal to or less than 300 meters, and the uplands comprising of areas that are above 300 meters. We used the categorization to factor the height components of the communities into decision making regarding their vulnerability.

\section{Creation of Buffer Zones around the Niger-Benue River}

In addition to height factor, the intensity of flood is generally known to be a function of the proximity of any location to the main causal water body. Consequently, communities that were found in closer proximity to River Niger and River Benue were regarded as being exposed to higher flood risk, though, depending on the topography of the area. In order to assess the vulnerability of the 256 communities to flood risk, a $3 \mathrm{~km}$ buffer zone was created along the Niger-Benue river. This was based on the average furthest distance of all the communities that are reported to be extremely affected during seasonal flood in the area, particularly the account of 2012 nation-wide flood [16], [21].

\section{E. Flood Risk and Vulnerability Zoning}

Flood risk and vulnerability of the 256 communities was assessed based on their proximity to river Niger and Benue, the $3 \mathrm{~km}$ buffer around Niger and Benue river, river NigerBenue basin and the heigh components of their geographical locations as made conspicuous by the DEM. The communities were grouped into four vulnerability zones and the zoning method was adopted from Ikusemoran et al. [15], as follows:

i. Highly vulnerable: All the communities located within the $3 \mathrm{~km}$ buffer.

ii. Vulnerable: All the communities located in the Niger-Benue River Basin.

iii. Marginally Vulnerable: All the communities located in river Niger and river Benue plains.

iv. Not Vulnerable: All the communities located in the upland areas.

\section{F. Creation of Choropleth Maps}

Choropleth maps of community counts by Local Government Areas (LGAs) was created for the respective flood vulnerability zones. This was achieved by joining the communities in each vulnerability zones with their respective LGAs using spatial join tool in the Analysis toolbox. These maps can enhance effective and efficient flood risk intervention plan/policy as well as making quick decisions during flood events, such as determining which LGAs require more attention based on their respective number of communities at risk and the degrees of their vulnerability. It also revealed LGAs with relatively higher number of not vulnerable communities thereby indicating possible locations for temporary and/or permanent refugee/shelter camps development in the State.

\section{RESUlTS AND DISCUSSION}

\section{A. Flood Vulnerability of Kogi Communities}

The varying degrees of vulnerability of Kogi State's communities to River Niger and River Benue is summarised in Table I and their spatial distribution is visualised in Fig. 3.

\begin{tabular}{cccc}
\multicolumn{4}{c}{ TABLE I: } \\
\multicolumn{4}{c}{ STATISTICS OF FLOOD VULNERABILITY OF COMMUNITIES IN } \\
KOG STATE \\
\hline S/N & Vulnerability Level & Number & Percentage $(\%)$ \\
\hline 1 & Highly Vulnerable & 33 & 12.89 \\
2 & Vulnerable & 64 & 25.00 \\
3 & Marginally vulnerable & 64 & 25.00 \\
4 & Not Vulnerable & 95 & 37.11 \\
& Total & 256 & 100 \\
\hline
\end{tabular}

Source: Data Analysis (2021).

Out of the total 256 communities, 33 representing $12.89 \%$ were located either on the river banks or the $3 \mathrm{~km}$ buffer and thus, were described as "highly vulnerable". Also, 64 communities representing $25 \%$ were located within the Niger-Benue Basin and were designated "vulnerable". Although these "vulnerable" communities are also susceptible to flood, their susceptibility is at a lesser degree of vulnerability than the "highly vulnerable" ones. Furthermore, another 64 communities were found within the Niger-Benue River plains, and these constituted the "marginally vulnerable". These 64 communities are equally liable to being inundated but at a minimal intensity. Therefore, they require less attention than the "highly vulnerable" and the "vulnerable" communities. The rest 95 
communities representing 37.11\% accounted for the "not vulnerable" communities.

These 47 communities constituted those that are located on relatively higher areas (uplands) and further from River Niger and River Benue. The findings of this study implies that as much as $161(62.89 \%)$ communities (highly vulnerable, vulnerable and marginally vulnerable) are exposed to varying degrees of flood risk, out of which 97 representing $37.89 \%$ (highly vulnerable and vulnerable) are directly exposed to the disastrously effects of flood in the study area.

This finding failed to agree with Aderoju et al. [16] who reported that only 73 communities were directly affected during the 2012 flood in Kogi State. This could be due to the smaller number of communities (156) sampled in their study as against the number (256) used in this study. Fig. 3 visualises the spatial distribution of communities and their degree of vulnerability.

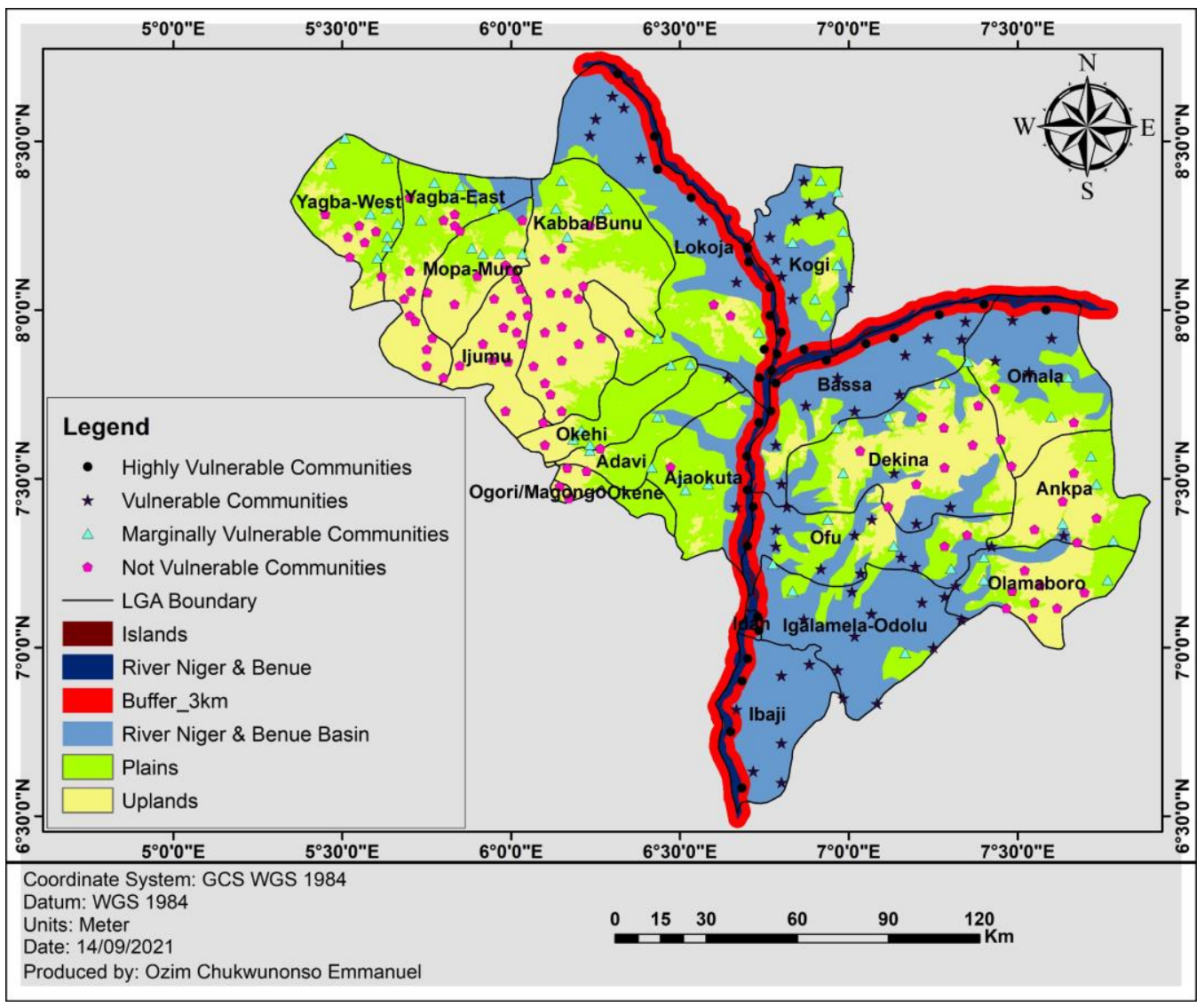

Fig. 3: Flood Vulnerability of Communities in Kogi State Source: Data Analysis (2021).

\section{B. Highly Vulnerable Communities}

Table II and Fig. 4 to Fig. 6 present the statistics of communities that are highly vulnerable to river Niger and Benue flooding, their spatial distribution and the choropleth map that depicts the number in the respective LGAs.

Table II and Fig. 4 revealed that out of the 33 communities identified as highly vulnerable, $27.27 \%$ are located on the river banks whereas $72.73 \%$ are located within $3 \mathrm{~km}$ distance from the river banks. Visual assessment of fig. 5 shows that majority of the river bank communities are located within Lokoja (Agodo, Denbor and Gunji Twaki), Kogi (Jamata, Numai and Okume) and Ajaokuta (Ajaokuta and Eroko) LGAs, and represented $33.33 \%, 33.33 \%$ and $22.22 \%$ of the total river bank communities, respectively. (37.5\%) of the communities located on river banks are found in Kogi LGAs (Jamats, Numai and Okume) followed by the $25.0 \%$ in Lokoja LGA (Agodo and Denbor). One (1) community representing $11.2 \%$ was found to be located Bassa LGA (Icheu).

TABLE II: STATISTICS OF THE Highly VULNERABLE COMMUNITIES

\begin{tabular}{|c|c|c|c|c|c|c|}
\hline \multirow{2}{*}{ LGA } & \multicolumn{2}{|c|}{ River Bank } & \multirow{2}{*}{ List of Communities } & \multicolumn{2}{|c|}{ Buffer Zone } & \multirow[t]{2}{*}{ List of Communities } \\
\hline & $\mathrm{N}$ & $\%$ & & $\mathrm{~N}$ & $\%$ & \\
\hline Ajaokuta & 2 & 22.22 & Ajaokuta, Eroko & 1 & 4.17 & Kuroko \\
\hline Bassa & 1 & 11.12 & Icheu & 6 & 25.00 & $\begin{array}{c}\text { Atakpa, Mozum, Oguma, Suli, } \\
\text { Akpaku, Amara }\end{array}$ \\
\hline Ibaji & 0 & 0.00 & - & 4 & 16.67 & Ota, Ogaine, Ogwo, Oje \\
\hline Idah & 0 & 0.00 & - & 2 & 8.33 & Idah, Ojigagala \\
\hline Kogi & 3 & 33.33 & Jamata, Numai, Okume & 2 & 8.33 & Adama, Dangerri \\
\hline Lokoja & 3 & 33.33 & Agodo, Denbor, Gunji Twaki & 6 & 25.00 & $\begin{array}{c}\text { Lokoja, Banda, Adana, Dere, Budon, } \\
\text { Sunawa }\end{array}$ \\
\hline Ofu & 0 & 0.00 & - & 2 & 8.33 & Itobe, Okokengi \\
\hline Omala & 0 & 0.00 & - & 1 & 4.17 & Bagana \\
\hline Total & 9 & 100.00 & & 24 & 100.00 & \\
\hline$\%$ of Total & 27.27 & & & 72.73 & & \\
\hline
\end{tabular}




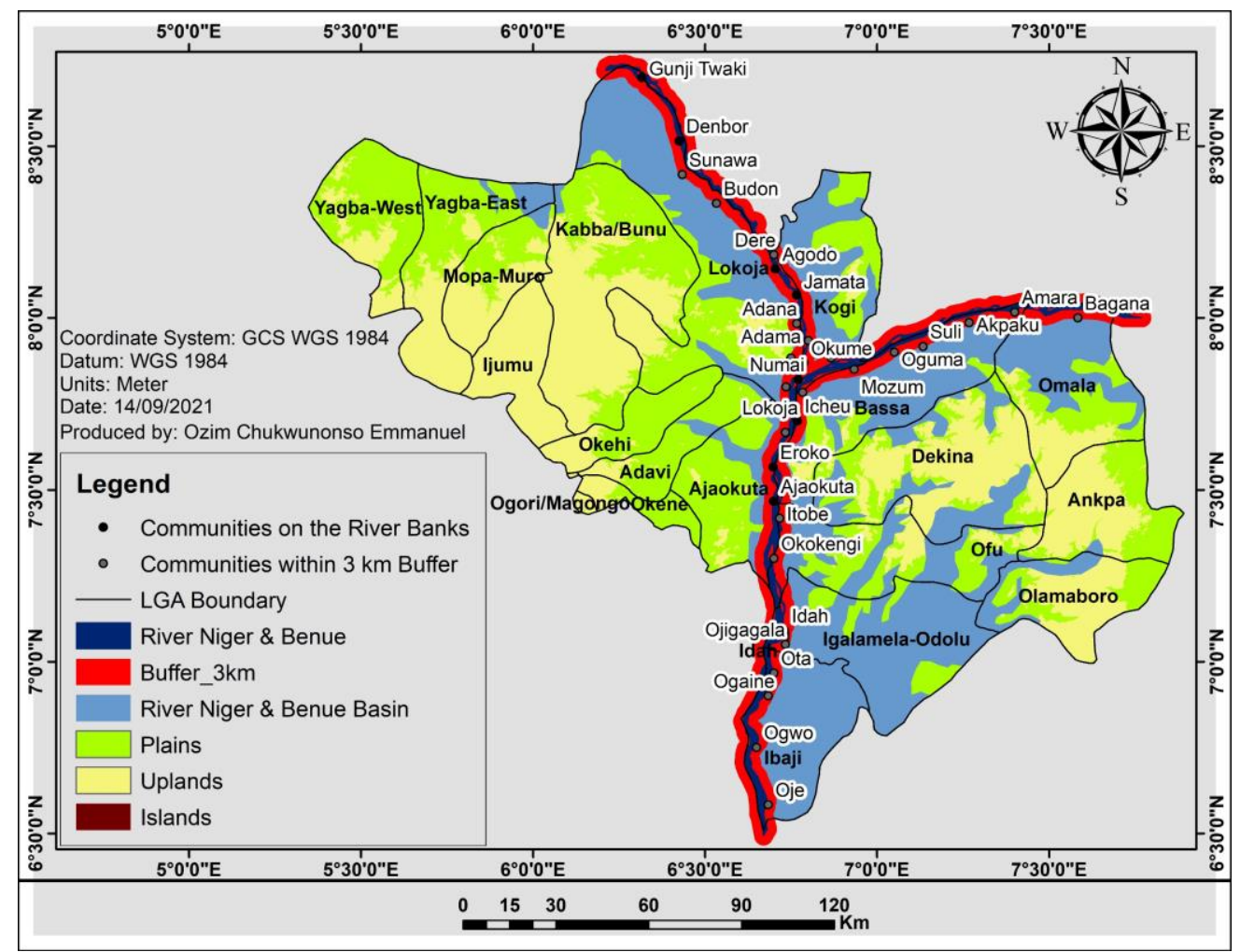

Fig. 4. Spatial Distribution of Highly Vulnerable Communities. Source: Data Analysis 2021.

Furthermore, it can be easily deduced from Fig. 5 that majority (25\%) of the 24 communities within $3 \mathrm{~km}$ distance from the river banks are geographically located in each of Bassa (Atakpa, Mozum, Oguma, Suli, Akpaku and Amara) and Lokoja (Lokoja, Banda, Adana, Dere, Budon and Sunawa) LGAs, followed by $16.67 \%$ in Ibaji (Ota, Ogaine, Ogwo and Oje). Conversely, only $8.33 \%$ was found in each of Idah, Kogi and Ofu and $4.17 \%$ in Ajaokuta and Omala LGAs.

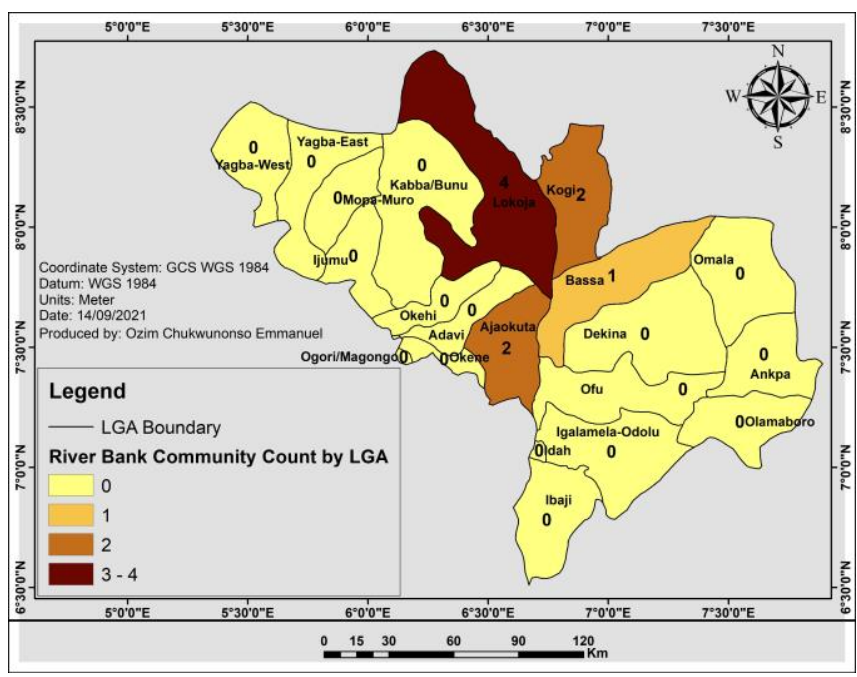

Fig. 5. Spatial Distribution of River Bank Communities by LGA. Data Analysis (2021).

This finding implies that Bassa, Lokoja and Ibaji are the LGAs with highest number of highly vulnerable communities in Kogi State. Kogi and Lokoja LGAs in particular with as much as three communities each, on the river banks, have more communities in closer proximity to the Niger-Benue rivers and these communities are constantly exposed to the disastrous impact of flooding in the State. This finding corroborates Aderoju et al. [16] who found that most of the affected communities in Kogi State, during the 2012 nationwide flood were those located in Lokoja, Bassa, Ajaokuta, Ofu, Idah and Ibaji LGA. However, their study failed to capture the affected communities in Kogi, Idah and Omala LGA.

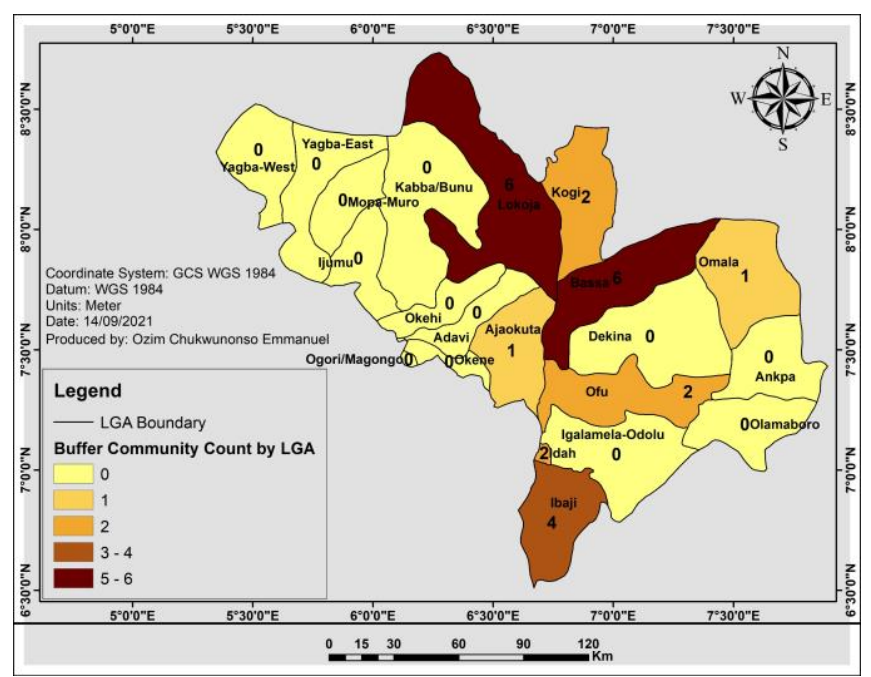

Fig. 6. Spatial Distribution of Buffer Zone Communities by LGA. Data Analysis (2021).

\section{Vulnerable Communities}

The vulnerable communities are comprised of those located within the Niger-Benue river Basin. Table III presents a statistical summary of their distribution in the study area whereas Fig. 7 and Fig. 8 visualises their spatial distribution and numbers by LGAs. 
TABLE III: STATISTICS OF THE VULNERABLE COMMUNITIES

$\begin{array}{llcr}\text { LGA } & \mathrm{N} & \text { Percent (\%) } & \text { List of Communities }\end{array}$

$\begin{array}{ccc}\text { Adavi } & 1 & 1.56 \\ \text { Ajaokuta } & 1 & 1.56\end{array}$

$\begin{array}{lll}\text { Ankpa } & 2 & 3.13\end{array}$

Bassa $\quad 8 \quad 12.50$

Dekina $\quad 5 \quad 7.81$

$\begin{array}{lll}\text { Ibaji } \quad 5 & 7.81\end{array}$

Idah $\quad 2 \quad 3.13$

Igalamela Odolu $\quad 11 \quad 17.19$

Kogi $\quad 9 \quad 14.06$

$\begin{array}{lll}\text { Lokoja } & 7 & 10.94\end{array}$

Ofu $\quad 9 \quad 14.06$

Omala $\quad 4 \quad 6.25$

Total

$64 \quad 100$

Source: Data Analysis (2021).

A total of 64 communities were found to be vulnerable in the study area out of which majority $(17.19 \%)$ are located in Igalamela-Odolu LGA, followed by $14.06 \%$ located in each of Kogi and Ofu LGAs. Other LGAs found to have substantial number of vulnerable communities as depicted in fig. 8 are Bassa with $12.5 \%$, Lokoja with $10.94 \%$ and Dekina and Ibaji with $7.81 \%$ each, as well as Omala with $6.25 \%$. LGAs that accounted for relatively lower numbers of vulnerable communities include: Adavi and Ajaokuta which accouted for $1.56 \%$ each with $12.68 \%$ each, and Ankpa and Idah with $3.13 \%$ each. This finding implies that majority of the vulnerable communities in the study area have their geographical locations in Igalamela-Odolu, Kogi, Ofu, Bassa, Lokoja, Dekina, Ibaji and Omala LGAs, hence these LGAs in addition to those hosting the highly vulnerable communities require more urgent attention towards finding mitigating measures to the rampaging seasonal flood events in the study area. This finding is also in agreement with all the communities identified by Aderoju et al. [16] as the most affected during the 2012 nationwide flood.

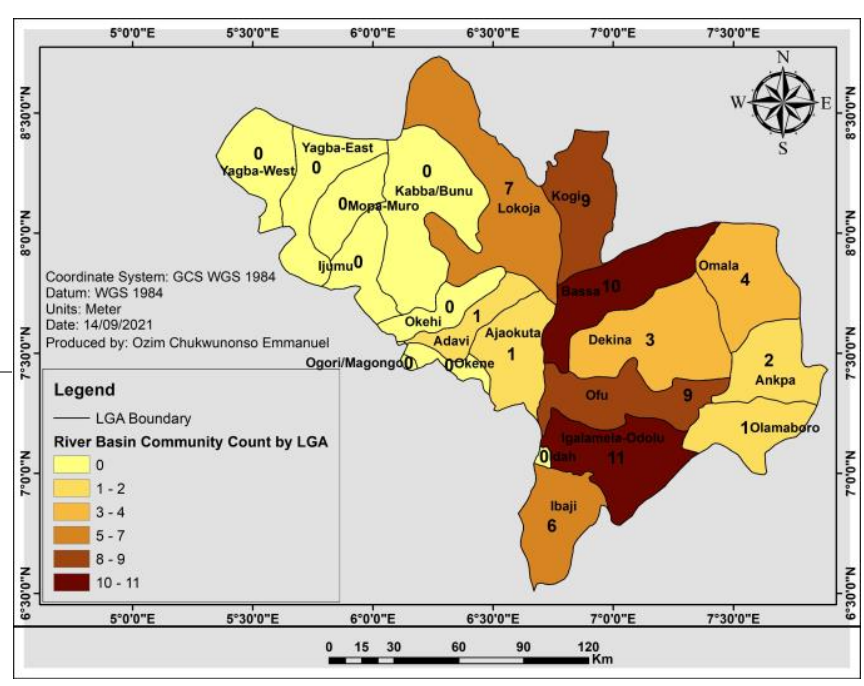

Fig. 8. Spatial Distribution of Vulnerable Communities by LGA. Data Analysis (2021).

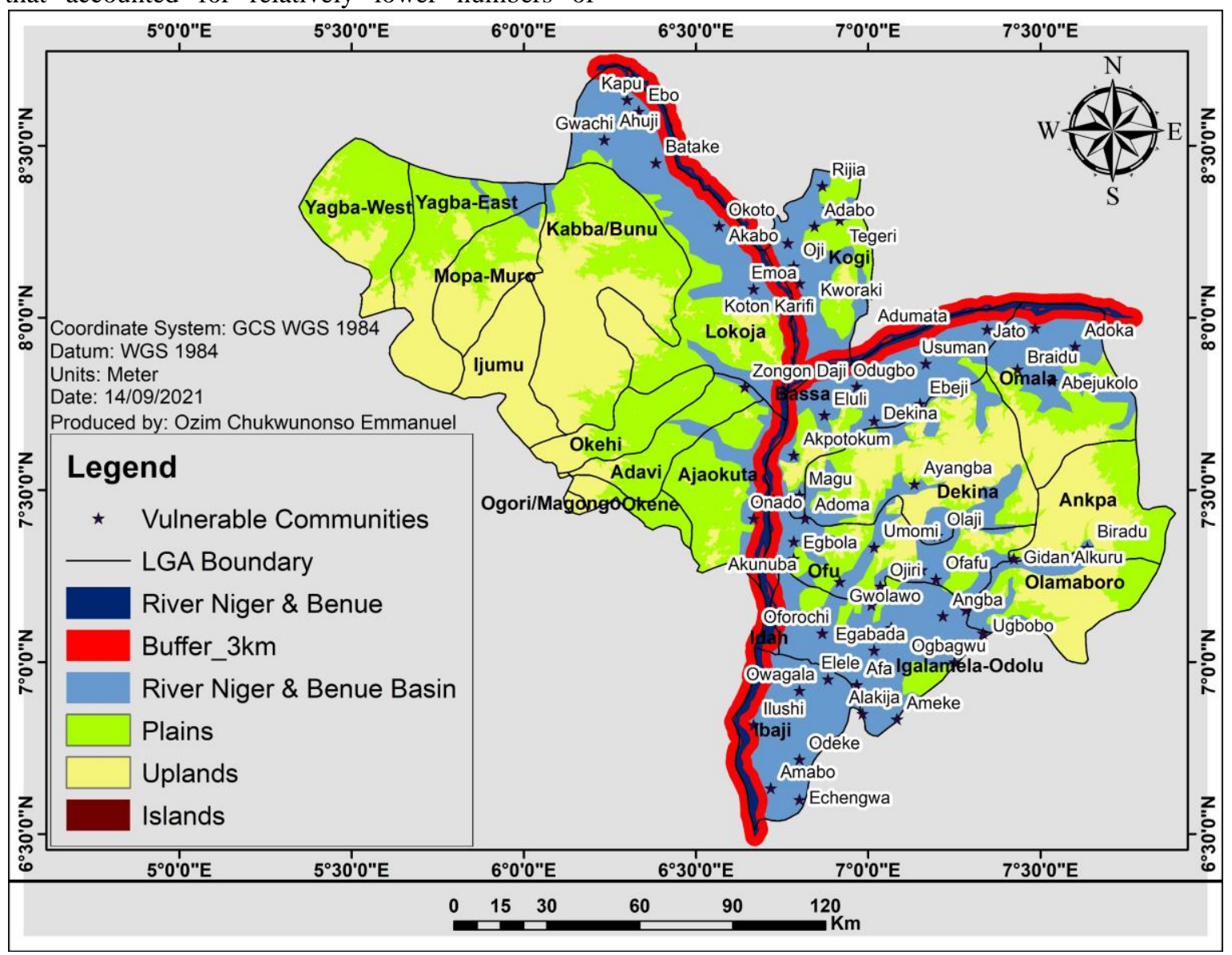

Fig. 7. Spatial Distribution of the Vulnerable Communities. Source: Data Analysis (2021). 


\section{Marginally Vulnerable Communities}

The marginally vulnerable communities comprise of those that were found to be located within the Niger-Benue river floodplains. The statistical summary of marginally vulnerable communities, their spatial distribution, and the spatial distribution by number per LGA are described and visualised in Table IV and Fig. 9 to Fig. 10.

TABLE IV: STATISTICS OF THE MARGINALLY VULNERABLE COMMUNITIES

\begin{tabular}{cccc}
\hline LGA & N & $\begin{array}{c}\text { Percent } \\
(\%)\end{array}$ & List of Communities \\
\hline Adavi & 2 & 3.13 & Bako, Osara \\
Ajaokuta & 4 & 6.25 & Ebiya, Idibo, Iloshi, Ugoli \\
Ankpa & 4 & 6.25 & Ankpa, Hoche, Ika, Okenyi \\
Dekina & 4 & 6.25 & Egudi, Emewe, Okpakiri, Opada \\
Igalamela Odolu & 3 & 4.69 & Adoni, Ajaka, Ogogba \\
Kabba/Bunu & 6 & 9.37 & Akutukpa, Guguriji, Junyura, \\
& & & Momodu, Shado, Shomulekiri \\
Kogi & 7 & 10.93 & Abehu, Egwogo, Iregbeta, \\
& & & Mekworo, Ogwaje Abaji, Sasere, \\
Lokoja & 2 & 3.13 & Zagi \\
Mopa Muro & 4 & 6.25 & Agbele, Aiyede, Jagbe, Taketi \\
Ofu & 3 & 4.69 & Alogi, Efaku, Okama \\
Okehi & 5 & 7.81 & Akpata, Ogaminan, Okaito, \\
Olamaboro & 3 & 4.69 & Usungwe, Adankolo \\
Omala & 3 & 4.69 & Anambra, Eke, Otuapa \\
Yaba East & 5 & 7.81 & Abakpa, Ado, Oliya \\
Yaba West & 9 & 14.06 & Ejiba, Iddo, Isandu, Ese, Odo Eri, \\
Total & 64 & 100 & Ofi, Ogbom, Ogga, Okoloki, Omi \\
\hline Source
\end{tabular}

The study found that 64 communities are marginally vulnerable to the seasonal Niger-Benue river flooding in the study area. A visual assessment of fig. 10 reveals that Yaba West LGA with $9(14.06 \%)$ communities, Kogi with 7 $(10.93 \%) \mathrm{Kabba} / \mathrm{Bunu}$ with $6(9.37 \%)$, each of Okehi and Yaba East with $5(7.81 \%)$, constituted the communities with high numbers of marginally vulnerable communities in the study area. Each of Ajaokuta, Ankpa, Dekina and MopaMuro LGAs have 4 marginally communities representing $6.25 \%$. These were closely followed by Igalamela Odolu, Ofu, Olamaboro and Omala LGAs with $3(4.69 \%)$ each. Only 2 communities representing $3.13 \%$ were found to be marginally vulnerable in each of Adavi and Lokoja LGAs.

This finding implies that considerable number of communities in Yagba West, Kogi, Kabba/Bunu, Okehi, Yagba East, Ajaokuta, Ankpa, Dekina and Mopa Muro LGAs are only exposed to minimal effects of the seasonal flood disaster in the study area. All of these communities are further apart from the River Niger and River Benue and/or located on relatively higher terrain/elevation compared to those found to be either highly vulnerable or vulnerable to flooding. This finding corroborates several authors [24], [25] who found/noted that the further away a phenomenon of interest is from waterbody and the higher the elevation above sea level, the more minimal the effect of flood on such phenomenon.

Source: Data Analysis (2021).

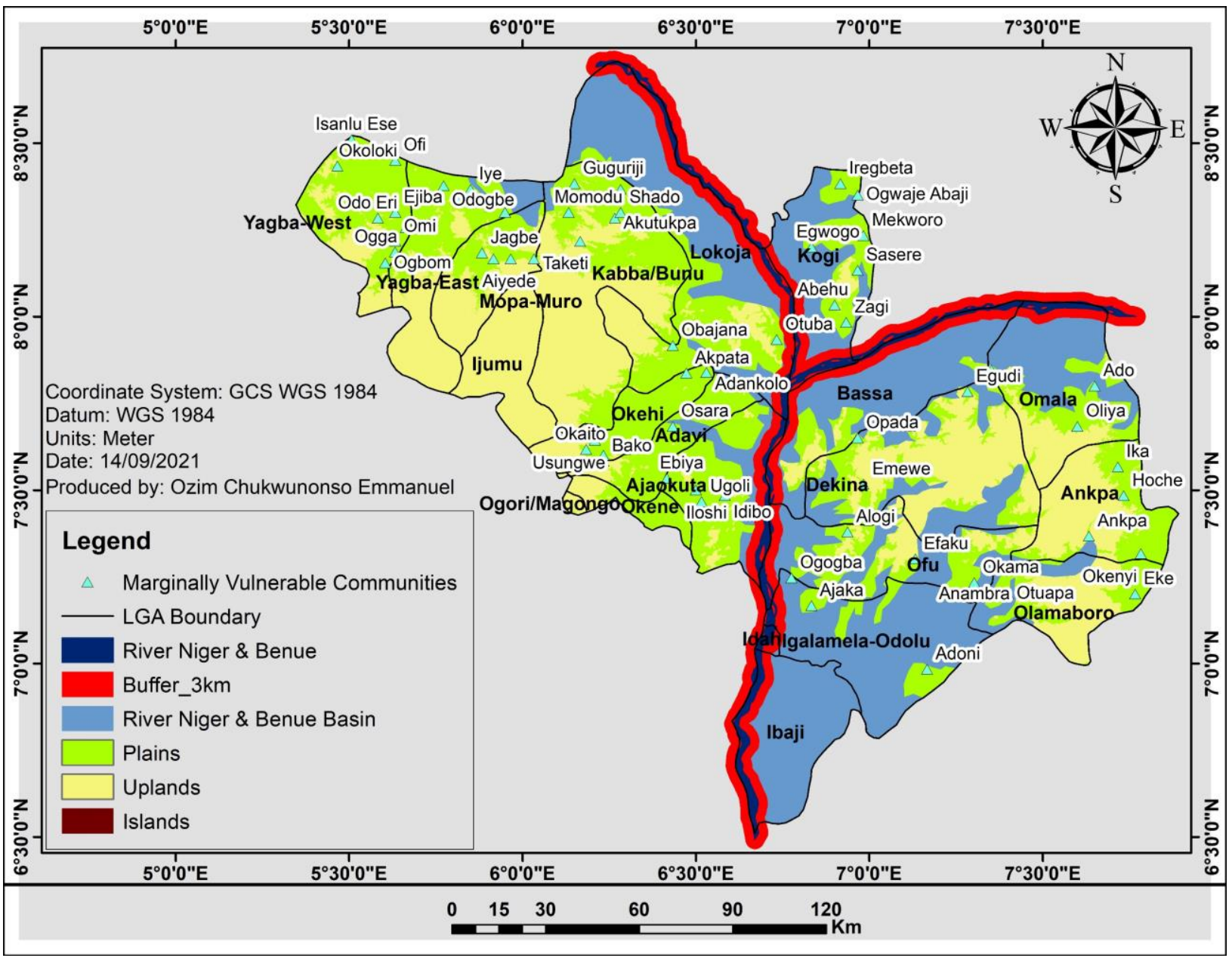

Fig. 9. Spatial Distribution of Marginally Vulnerable Communities. Source: Data Analysis (2021). 


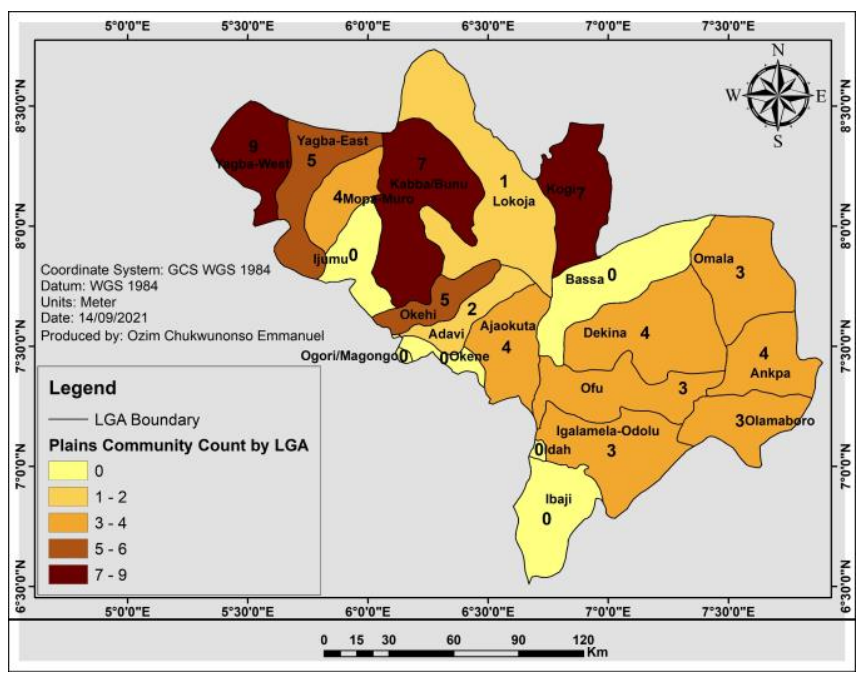

Fig. 10. Spatial Distribution of Marginally Vulnerable Communities by LGA. Source: Data Analysis (2021).

\section{E. Not Vulnerable Communities}

Communities that were found to be located in the upland areas were designated "not vulnerable" to Niger-Benue river flood risk. The statistical summary, spatial distribution, and the spatial distribution by number per LGAs of the marginally vulnerable communities are presented/depicted in table $\mathrm{V}$ and Fig. 11 to Fig. 12.

Table V and Fig. 12 reveal that a total of 95 communities were identified as 'not vulnerable' to the habitual seasonal flooding of Niger-Benue rivers in the study area. Ijumu, Kabba/Bunu, Yaba East are LGAs with significant number of vulnerable communities with 16 (16.84\%), 15 (15.79\%) and $14(14.74 \%)$ respectively. Other LGAs with relatively high numbers of not vulnerable communities include Dekina, Olamaboro and Yaba West with 8 communities each, representing 8.42\%, Ankpa and Mopa Muro with 6 (6.31\%) each as well as Omala with 4 representing $4.21 \%$. On the contrary, only $2(2.11 \%)$ not vulnerable communities were identified in each of Lokoja, Ogori/Magongo, Okehi and Okene, and $1(1.05 \%)$ in Ajaokuta and Idah LGAs.
This finding indicates that most communities in Ijumu, Kabba/Bunu and Yaba East as well as some in Dekina and Olamaboro have potentials of becoming siting locations for flood shelter/refugee camps at any event of flood in the study area. Furthermore, it implies that all the communities in Adavi, Bassa, Ibaji, Igalamela Odolu, Kogi and Ofu LGAs are exposed to one degree of vulnerability or another as none was found among the not vulnerable communities. The findings are also consistent with Aderoju et al. [16] who stated that higher terrains are noticeable around Ijumu LGA due to the presence of Agbaja Plateau and Okoro-Agbo hills in the area. Hence, majority of the not vulnerable communities were found around the LGA.

TABLE V: StATISTICS OF THE Not VULNERABLE COMMUNITIES

\begin{tabular}{|c|c|c|c|}
\hline LGA & $\mathrm{N}$ & $\begin{array}{l}\text { Percent } \\
(\%)\end{array}$ & List of Communities \\
\hline Ajaokuta & 1 & 1.05 & Eganyi \\
\hline Ankpa & 6 & 6.31 & $\begin{array}{c}\text { Agojeju, Aguma, Aku, Ede, Okaba, } \\
\text { Ofugo }\end{array}$ \\
\hline Dekina & 8 & 8.42 & $\begin{array}{c}\text { Acharu, Alojori, Egume, Elubi, Iyale, } \\
\text { Onugba, Onukpo, Sanioko }\end{array}$ \\
\hline Idah & 1 & 1.05 & Bugobi \\
\hline Ijumu & 16 & 16.84 & $\begin{array}{c}\text { Aiye, Aiyegunle, Aiyetoro, Araromi, } \\
\text { Ayere, Dokoro, Ekinrin, Iddo, Idoyi, } \\
\text { Illa,Ilukpa, Iyara, Ogale, Ogali, Okoro, } \\
\text { Otunade }\end{array}$ \\
\hline Kabba/Bunu & 15 & 15.79 & $\begin{array}{l}\text { Agbedde, Akpara, Ape, Igba, Kabba, } \\
\text { Kakun, Oduape, Offere, Ohaketi, } \\
\text { Okebukun, Okpa, Olle, Ora, Otu, Suku }\end{array}$ \\
\hline Lokoja & 2 & 2.11 & Agbaja, Choko Choko \\
\hline Mopa Muro & 6 & 6.31 & $\begin{array}{c}\text { Ayiedero, Bajogun, Ejuku, Ilai, Mopa, } \\
\text { Okagi }\end{array}$ \\
\hline Ogori/Magongo & 2 & 2.11 & Magongo, Ogori \\
\hline Okehi & 2 & 2.11 & Adugi, Eika \\
\hline Okene & 2 & 2.11 & Adabi, Okene \\
\hline Olamaboro & 8 & 8.42 & $\begin{array}{l}\text { Ayangba, Edipe Eke, Erong, Ike, } \\
\text { Ogugu, Ogbe, Okpo, Oledo }\end{array}$ \\
\hline Omala & 4 & 4.21 & Agbada, Igodo, Ogboyoga, Olah \\
\hline Yaba East & 14 & 14.74 & $\begin{array}{c}\text { Aiyede, Eluke, Ife, Igbagun, Ijowa, } \\
\text { Isanlu Itedo, Isanlu Makutu, Isanlu } \\
\text { Mopo, Iya, Jege, Kpoinya, Onari, } \\
\text { Opota Egboro, Ponyan }\end{array}$ \\
\hline Yaba West & 8 & 8.42 & $\begin{array}{l}\text { Egbe, Koro, Odo Ere, Odo Pete, } \\
\text { Odosin, Ogbe, Okere, Okurun }\end{array}$ \\
\hline Total & 95 & 100 & \\
\hline
\end{tabular}
Source: Data Analysis (2021).

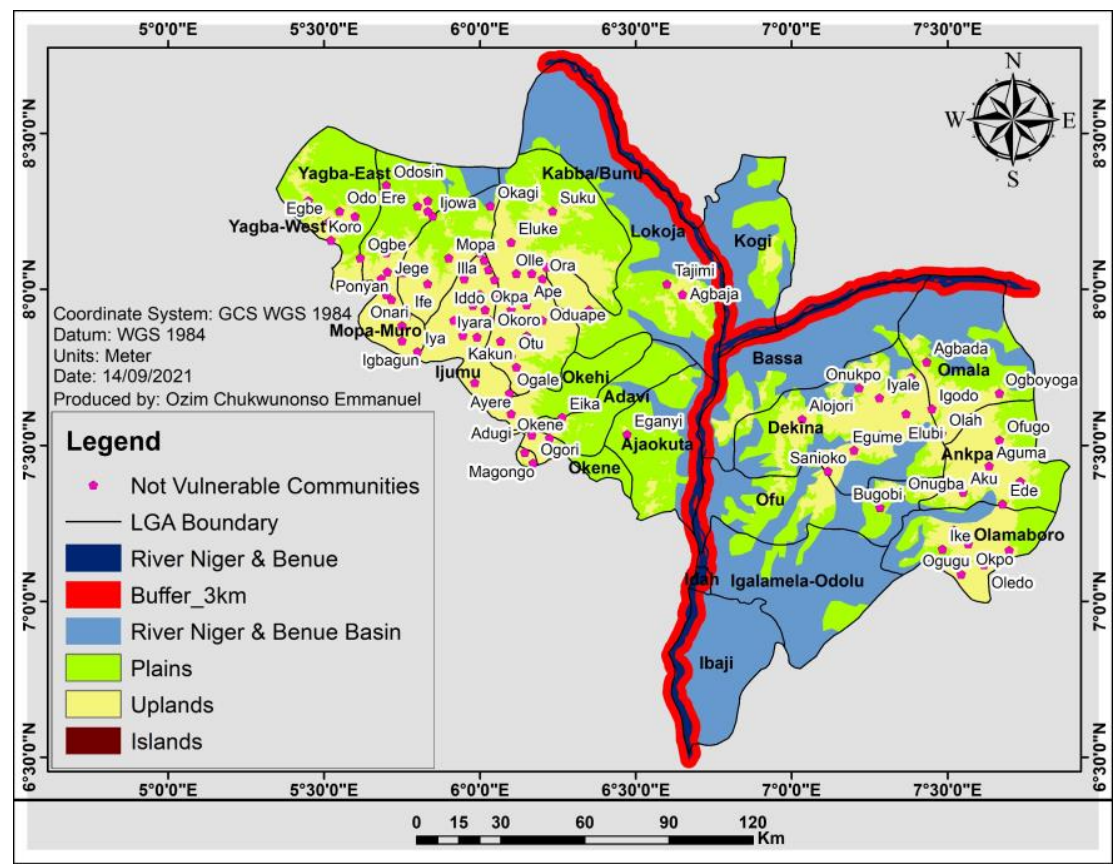

Fig. 11. Spatial Distribution of "Not Vulnerable" Communities. Source: Data Analysis (2021). 


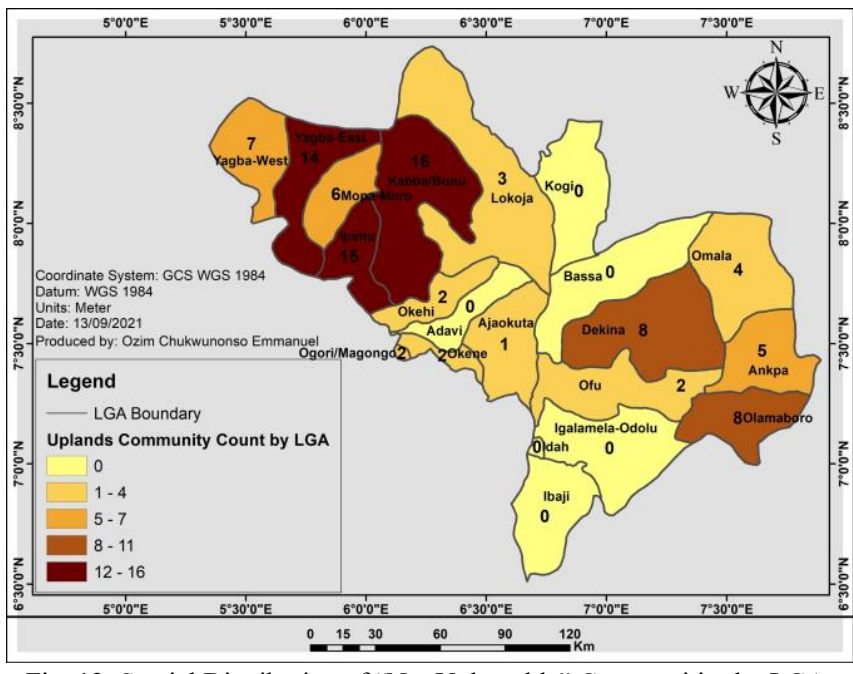

Fig. 12: Spatial Distribution of "Not Vulnerable" Communities by LGA Source: Data Analysis (2021).

\section{CONCLUSION}

Flood risk and vulnerability analysis is a vital component for appropriate land use planning in flood-prone areas. It creates easily read, rapidly accessible charts and maps that can facilitate administrators and planners to identify areas at risk and prioritize their mitigation and response efforts. This study has generated such easily read and accessible maps to help appropriate national, state and LGA level authorities with the task of effective and efficient land use planning in Kogi State. Given the low-lying nature of most LGAs in Kogi State, a large number (161) her communities are exposed to varying degrees of flood vulnerability (highly vulnerable, vulnerable or marginally vulnerable). Hence, this study recommends that: the highly vulnerable communities, beginning with the 9 located on river banks be relocated to higher terrains and future settlement development should be discouraged in the zone by the collaborative efforts of the State and LGA authorities; the concerned Government and Non-Governmental Agencies should design effective plan for urgent evacuation of people from the highly vulnerable communities to safety grounds during flood events and proper early warning and effective town planning measures should be put in place in the vulnerable and marginally vulnerable zones. Finally, further studies should be conducted in Ijumu, Kabba/Bunu, Yaba West, Yaba East, Mopa Muro, Dekina and Olamaboro LGAs in view of identifying most suitable locations for possible flood shelter/refugee camp development in the study area.

\section{REFERENCES}

[1] S. D. Brody, S. Zahran, W. E. Highfield, H. Grover, and A. Vedlitz "Identifying the impact of the built environment on flood damage in Texas", Oxford, Blackwell Publishing, 2007.

[2] D. Schramn and R. Dries "Natural hazard; causes and effects", U.S.A, University of Wisconson, 1986.

[3] A. C. C. Ezeabasili, and A. U. Okonkwo, "Climate change impacts on the built environment in Nigeria", African Research Review, vol. 7(4), pp. 288-303, 2013.

[4] D. N. Jeb, and S. P. Aggarwal, "Flood inundation hazard modeling of the River Kaduna using remote sensing and geographic information systems", Journal of Applied Sciences Research, vol. 4 (12), pp 1822 . 1833.

[5] European Commission (EC), "Directive 2007/60/EC of the European Parliament and of the Council of 23 October, 2007 on the assessment and management of flood risks", Official Journal of the European Union, L288, pp 27-34. 2007.

[6] N. O. Adeoye, A. Ayanlade, and O. Babatimehin, "Climate change and menace of floods in Nigerian cities: socio-economic implications", Advances in Natural and Applied Sciences, vol. 3 (3), pp 369-377, 2009.

[7] M. Nmeribeh, "Kano's flood disaster", The NEWS. 2011

[8] S. Balabanova, V. Vassilev, "Creation of flood hazard maps", BALWOIS 2008-Ohrid, Republic of Macedonia, 25, 2008.

[9] Y. Kwak, and A. Kondoh, "A study on the extraction of multi-factor influencing floods from RS image and IS data; a case study in Nackdong Basin, S.Korea", The International Archives Of The Photogrammetry, Remote Sensing And Spatial Information Sciences, ISPRS Congress Beijing 2008, 37, Part B8, Commission VIII, pp. 421426.

[10] A. J. Askew, "Water in the International Decade for Natural Disaster Reduction. In Leavesley et al., (eds) Destructive Water: Water-caused Natural Disasters, their Abatement and Control. IAHS. Publication No. 239. 1999.

[11] Simonovic, P. Slobdan, "A new method for spatial and temporal analysis of risk in water resources management", Journal of Hydro informatics, vol. 11(3,4), pp. 320-329, 2009.

[12] C. Ezigbo, "Losses from 2012 flood hits N2.1Trillion, ThisDay Live", Available online http://www.thisdaylive.com/articles/nema-lossesfrom-2012-flood-hits-n2-1trillion/159522/.

[13] Centre for Human Security of the Olusegun Obasanjo Presidential Library Foundation (CHSOOPLF), Building a Coordinated Approach to Flood Disasters in Nigeria, (2013) Available online: http://centreforhumansecurity.org/, $\quad$ http://www.nema.gov.ng/, http://anewnaija.org/.

[14] O. H. Adedeji, B. O. Odufuwa, and O. H. Adebayo, "Building capabilities for flood and hazard preparedness and risk reduction in Nigeria: need for spatial planning and land management", Journal of sustainable Development in Africa, vol. 14 (1), 45-58, 2013.

[15] Ikusemoran Mayomi, Anthony Dami and U. M. Maryah, "GIS Based Assessment of Flood Risk and Vulnerability of Communities in the Benue Floodplains, Adamawa State, Nigeria". Journal of Geography and Geology; Vol. 5, No. 4; 2013 ISSN 1916-9779 E-ISSN 1916-9787, Published by Canadian Center of Science and Education.

[16] M. Aderoju Olaide, Jantiku Jagila, A. Fagbemiro Olayinka, Aliyu Imrana, K. Nwadike Blessing, E. Ajonye Susan, S. Salman Khalid, IOSR Journal of Environmental Science, Toxicology and Food Technology (IOSR-JESTFT) e-ISSN: 2319-2402, p-ISSN: 2319-2399. Vol. 8, Issue 2 Ver. IV (PP 74-84), 2014. www.iosrjournals.org.

[17] NASA-National Aeronautics and Space Administration, "Flood in Nigeria, http://earthobservatory.nasa.gov/IOT/view.php?id=79404

$2012 "$

8] S. Ishaya, O. O. Ifatimehin and I. B. Abaje, "Mapping Flood Vulnerable Areas in a Developing Urban Centre of Nige ria," Journal of Sustainable Development in Africa, Vol. 11, No. 4, pp. 180194.2009.

[19] O. O. Ifatimehin, S. D. Musa, \& J. O. Adeyemi, "An Analysis of the Changing Land use and its Impact of the Environment of Kogi State", Journal of Sustainable Development in Africa, Vol. 10(4), 357-364. 2009.

[20] A. A. Musilimu, I. A. Tolu and O. I. Ismaila, "Assessment of Solid Waste Management in Kogi State". Jordan Journal of Earth and Environmental Sciences; Vol. 7 (2), pp. 103-108, Dec 2015, ISSN 1995-6681.

[21] M. L. Ojigi, F.I. Abdulkadir, M. O. Aderoju, "Geospatial Mapping and Analysis of the 2012 flooding Disaster in central parts of Nigeria" 8th GIS symposium, Dammaram, Saudi Arabia, 2013.

[22] A. Emmanuel Udo, O. C. Ojinnaka, C. N. Baywood, U. A Gift, "Flood Hazard Analysis and Damage Assessment of 2012 Flood in Anambra State Using GIS and Remote Sensing Approach" American Journal of Geographic Information System, vol. 4(1): 38-51, 2015. DOI: 10.5923/j.ajgis.20150401.03

[23] Felix Ndidi Nkeki, Philip John Henah, Vincent Nduka Ojeh, "Geospatial Techniques for the Assessment and Analysis of Flood Risk along the Niger-Benue Basin in Nigeria" Journal of Geographic Information System, vol. 5, pp. 123-135, 2013 http://dx.doi.org/10.4236/jgis.2013.52013 Published Online April 2013 (http://www.scirp.org/journal/jgis).

[24] G. O. Enaruvbe, and G. U. Yesuf, "Spatial analysis of flood disaster in Delta State, Nigeria", IFE Res. Public. Geography, vol. 11, pp. 52-58. 2012.

[25] F. N. Nkeki, P. J. Henah, and V. N. Ojeh, "Geospatial Techniques for the Assessment and Analysis of Flood Risk along the Niger-Benue Basin in Nigeria", Journal of Geographic Information System, vol. 5 , pp. 123-135, 2013. http://dx.doi.org/10.4236/jgis.2013.52013. 